\title{
Editorial
}

\section{Sports Materials Special Issue Editorial}

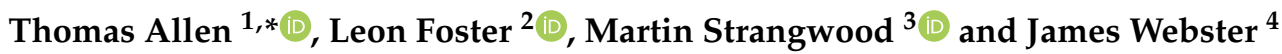 \\ 1 Department of Engineering, Manchester Metropolitan University, Manchester M15 6BH, UK \\ 2 Centre for Sports Engineering Research, Sheffield Hallam University, Sheffield S10 2BP, UK; \\ 1.i.foster@shu.ac.uk \\ 3 School of Metallurgy and Materials, The University of Birmingham, Edgbaston Birmingham B15 2TT, UK; \\ m.strangwood@bham.ac.uk \\ 4 Under Armour Inc, Baltimore 21230, UK; jwebster@underarmour.com \\ * Correspondence: t.allen@mmu.ac.uk
}

Received: 26 November 2019; Accepted: 28 November 2019; Published: 4 December 2019

Materials are key to the world of sport. Advances in materials have enhanced equipment and clothing to allow athletes to perform better and set new records, while improving safety and making sport and exercise more accessible, comfortable and enjoyable. Tennis saw dramatic changes in the 1980s, as sports engineers discarded wood and adopted fibre-polymer composites to produce stiffer rackets with larger heads [1]. Fibre-polymer composites are also used to create stiff plates within the midsole of some distance running shoes, allowing athletes to run more efficiently [2,3]. In snowsports, soft-shell back protectors made from shear thickening foam are more comfortable and offer better protection from repeat impacts than their traditional hard-shell counterparts [4]. The work behind such advances in materials and equipment should ideally be communicated in peer reviewed articles, so claims can be verified and improvements realised, and appropriately implemented and regulated, to ensure sport remains fair, safe and enjoyable for all.

This Special Issue on "Sports Materials" brings together 10 articles covering equipment testing, modelling and material development. As an established tool for designing and testing sports equipment and assessing materials [5], finite element modelling is clearly present in this issue. The global appeal of sports engineering is reflected in contributions from China, Taiwan, UK, Italy, Germany, France, Sweden and the USA.

The issue opens with an article from Corke and colleagues [6] on the effect of golf club handle gripping conditions on the ball-clubhead interaction. By measuring strain propagation along the shaft, the time for impact-induced vibrations to travel from the clubhead to the handle and back was shown to exceed the duration of ball-clubhead contact. Therefore, the way in which the club handle is gripped should not affect how the ball leaves the clubhead, meaning golf robots are comparable to human testers. Moving from hand-held equipment to ball dynamics, Lane and colleagues [7] measured strains in tennis ball cores during impacts with a rigid surface, using three-dimensional digital image correlation. Knowledge of the strains experienced by sports equipment during use can inform material characterisation and finite element modelling strategies, with implications for product development and selection.

The first article in the issue utilising finite element modeling is from Rinaldi and colleagues [8], and covers the oblique impact of a table tennis ball on the polymeric layers that are applied to the faces of wooden bats. Sports engineering is not always about product development and the latest innovations, with regulators often more concerned with maintaining tradition and ensuring fair and safe play. Fortin-Smith and coworkers $[9,10]$ present two articles on finite element models for investigating wooden baseball bat durability and failure mechanisms. They are interested in preventing potentially hazardous multi-piece failures, where a fragment of a broken bat can become a dangerous high-speed projectile. In the first article [9] they characterised the wood used in bats, developed the models and 
compared them to experiments, while in the second article [10] they used the models to investigate the effect of the slope of grain of the wood on bat failure. Cole et al. [11] developed finite element modelling techniques for predicting the response of artificial turf shock pads to vertical impact loading, with implications for surface design and regulation, as well as player-surface interactions.

Three articles in the issue cover materials for safety devices. The first of these articles was authored by Penta and coworkers [12], and showcases a meshless approach for modelling the impact response of polymeric foam crash mats, with implications for the design of foam protective devices. The meshless approach allowed the crash mat model to function under high strain deformation, where elements within a mesh are prone to distortion. Foster and colleagues [13] explored auxetic open cell foam as a replacement for the conventional open cell foam typically used as a comfort layer in sports helmets, showing potential for these alternative materials to reduce hazardous impact induced accelerations. Duncan and colleagues [14] present a comprehensive review of auxetic materials for sports applications, covering foams, additively manufactured structures and textiles. While these auxetic materials are appearing in sports products like helmets and athletic shoes, further work is required in their testing, modeling and manufacturing before their potential can be fully realised. The final article in the issue is from Lin et al., [15] and is concerned with the development of functional composite yarns for sportswear applications.

This Special Issue represents the current state-of-the-art in sport materials research. As athletes strive for ever increasing gains in performance and safety, and with consumers demanding higher levels of comfort, customisation and sustainability, we expect sporting goods brands to bring further materials driven innovations to their products. We see finite element modelling as a useful tool in the research and development of sports equipment and clothing utilising novel materials. We urge sports engineers to work closely with sports scientists to investigate equipment-athlete interactions [16,17], to ensure the improvements they envisage become reality.

Acknowledgments: The authors would like to thank Oliver Duncan for providing feedback on the editorial draft.

Conflicts of Interest: The authors declare no conflict of interest.

\section{References}

1. Taraborrelli, L.; Grant, R.; Sullivan, M.; Choppin, S.; Spurr, J.; Haake, S.; Allen, T. Materials Have Driven the Historical Development of the Tennis Racket. Appl. Sci. 2019, 9, 4352. [CrossRef]

2. Hoogkamer, W.; Kipp, S.; Frank, J.H.; Farina, E.M.; Luo, G.; Kram, R. A comparison of the energetic cost of running in marathon racing shoes. Sports Med. 2018, 48, 1009-1019. [CrossRef] [PubMed]

3. Hunter, I.; McLeod, A.; Valentine, D.; Low, T.; Ward, J.; Hager, R. Running economy, mechanics, and marathon racing shoes. J. Sports Sci. 2019, 37, 2367-2373. [CrossRef] [PubMed]

4. Signetti, S.; Nicotra, M.; Colonna, M.; Pugno, N.M. Modeling and simulation of the impact behavior of soft polymeric-foam-based back protectors for winter sports. J. Sci. Med. Sport. 2019, 22, S65-S70. [CrossRef] [PubMed]

5. Choppin, S.; Allen, T. Special issue on predictive modelling in sport. Proc. Inst. Mech. Eng. Part P J. Sports Eng. Technol. 2012, 226, 75-76. [CrossRef]

6. Corke, T.W.; Betzler, N.F.; Wallace, E.S.; Strangwood, M.; Otto, S.R. Implications of Rigid Gripping Constraints on Clubhead Dynamics in Steel Golf Shafts. Appl. Sci. 2018, 8, 422. [CrossRef]

7. Lane, B.; Sherratt, P.; Hu, X.; Harland, A. Measurement of Strain and Strain Rate during the Impact of Tennis Ball Cores. Appl. Sci. 2018, 8, 371. [CrossRef]

8. Rinaldi, R.G.; Manin, L.; Moineau, S.; Havard, N. Table Tennis Ball Impacting Racket Polymeric Coatings: Experiments and Modeling of Key Performance Metrics. Appl. Sci. 2019, 9, 158. [CrossRef]

9. Fortin-Smith, J.; Sherwood, J.; Drane, P.; Kretschmann, D. Characterization of Maple and Ash Material Properties for the Finite Element Modeling of Wood Baseball Bats. Appl. Sci. 2018, 8, 2256. [CrossRef]

10. Fortin-Smith, J.; Sherwood, J.; Drane, P.; Ruggiero, E.; Campshure, B.; Kretschmann, D. A Finite Element Investigation into the Effect of Slope of Grain on Wood Baseball Bat Durability. Appl. Sci. 2019, 9, 3733. [CrossRef] 
11. Cole, D.; Forrester, S.; Fleming, P. Mechanical Characterisation and Modelling of Elastomeric Shockpads. Appl. Sci. 2018, 8, 501. [CrossRef]

12. Penta, F.; Amodeo, G.; Gloria, A.; Martorelli, M.; Odenwald, S.; Lanzotti, A. Low-Velocity Impacts on a Polymeric Foam for the Passive Safety Improvement of Sports Fields: Meshless Approach and Experimental Validation. Appl. Sci. 2018, 8, 1174. [CrossRef]

13. Foster, L.; Peketi, P.; Allen, T.; Senior, T.; Duncan, O.; Alderson, A. Application of Auxetic Foam in Sports Helmets. Appl. Sci. 2018, 8, 354. [CrossRef]

14. Duncan, O.; Shepherd, T.; Moroney, C.; Foster, L.; Venkatraman, P.D.; Winwood, K.; Allen, T.; Alderson, A. Review of Auxetic Materials for Sports Applications: Expanding Options in Comfort and Protection. Appl. Sci. 2018, 8, 941. [CrossRef]

15. Lin, J.-H.; He, C.-H.; Huang, Y.-T.; Lou, C.-W. Functional Elastic Knits Made of Bamboo Charcoal and Quick-Dry Yarns: Manufacturing Techniques and Property Evaluations. Appl. Sci. 2017, 7, 1287. [CrossRef]

16. Stefanyshyn, D.J.; Wannop, J.W. Biomechanics research and sport equipment development. Sports Eng. 2015, 18, 191-202. [CrossRef]

17. Allen, T.; Choppin, S.; Knudson, D. A review of tennis racket performance parameters. Sports Eng. 2016, 19, 1-11. [CrossRef]

(C) 2019 by the authors. Licensee MDPI, Basel, Switzerland. This article is an open access article distributed under the terms and conditions of the Creative Commons Attribution (CC BY) license (http://creativecommons.org/licenses/by/4.0/). 